\title{
MINIMALIST DEVELOPMENTS IN INDIANA Constitutional LaW-Equal Privileges ProgresSes SLOWLY
}

\author{
ScotT ChinN* \\ Daniel E. Pulliam**
}

The Indiana Supreme Court left Indiana constitutional law static during the survey period while its membership went unchanged. ${ }^{1}$ Although another new member will likely join the court during the next survey period, nothing from the current survey period suggests the court will alter its current limited approach to developing new doctrines under the Indiana Constitution. The supreme court held Indiana's right-to-work law does not violate article 1, section 21 of the Indiana Constitution by taking a person's "particular services" without compensation and the denial of transportation services did not violate the Education Clause of the Indiana Constitution. ${ }^{2}$

Meanwhile, the court of appeals extended the law governing equal privileges and immunities into new areas and overturned several convictions sua sponte for violating Indiana's unique double jeopardy provision. ${ }^{3}$ The court of appeals also invalidated a misdemeanor disorderly conduct conviction for violating the free speech provision ${ }^{4}$ and came to different conclusions on whether the State's prohibition against synthetic drugs was unconstitutionally vague. ${ }^{5}$

Although the Indiana Supreme Court broke no new ground, incremental approaches by the court of appeals with equal privileges and immunities and its experimentation with unconstitutional vagueness could prompt the supreme court to address new areas of Indiana constitutional law. ${ }^{6}$

* Scott Chinn is a partner at Faegre Baker Daniels LLP practicing public sector law and litigation. B.A., 1991, Indiana University; J.D., 1994, Indiana University Robert H. McKinney School of Law. He is a former Editor-in-Chief of the Indiana International and Comparative Law Review. He clerked for Judge David F. Hamilton, then District Judge, U.S. District Court, Southern District of Indiana.

** Daniel Pulliam is an associate in the business litigation group at Faegre Baker Daniels, LLP. B.A., 2004, cum laude, Butler University, Indianapolis; J.D., 2010, magna cum laude, Indiana University Robert H. McKinney School of Law. He is a former Editor-in-Chief of the Indiana Law Review and The Butler Collegian and a former law clerk for Judge John Daniel Tinder on the United States Court of Appeals for the Seventh Circuit.

1. See Jon Laramore \& Daniel Pulliam, Developments in Indiana Constitutional Law: A New Equal Privileges Wrinkle, 48 IND. L. Rev. 1223 (2015).

2. Zoeller v. Sweeney, 19 N.E.3d 749 (Ind. 2014).

3. See Phillips v. State, 25 N.E.3d 1284 (Ind. Ct. App. 2015); Hatchett v. State, 33 N.E.3d 1125 (Ind. Ct. App. 2015); White v. State, 25 N.E.3d 107 (Ind. Ct. App. 2014), trans. denied, 34 N.E.3d 685 (Ind. 2015).

4. Jordan v. State, 37 N.E.3d 525 (Ind. Ct. App. 2015).

5. Compare Elvers v. State, 22 N.E.3d 824 (Ind. Ct. App. 2014), with Tiplick v. State, 25 N.E.3d 190 (Ind. Ct. App.), vacated, 43 N.E.3d 1259 (Ind. 2015).

6. The authors thank Elizabeth Little for her tremendous contribution in gathering material for this Article. 


\section{Equal Privileges and Immunities}

Whistle Stop Inn, Inc. v. City of Indianapolis ${ }^{7}$ concerns the constitutionality of the Indianapolis smoking ordinance. A group of bar owners claimed the ordinance's exceptions - which did not include them-violated the Equal Privileges and Immunities Clause. ${ }^{8}$ One such exception was directed at the single licensed off-track betting (OTB) facility in Marion County. ${ }^{9}$ The plaintiff bar owners alleged that the Indiana Supreme Court's decision in Paul Stieler Enterprises, Inc. v. City of Evansville, which struck down an Evansville smoking ordinance excepting the gaming riverboat from coverage, controlled the outcome of the Indianapolis ordinance. ${ }^{10}$ The owner of the OTB and the City of Indianapolis defended the exception by arguing (1) that in excepting the applicability of the ordinance to the OTB, the City was entitled to defer to the State Horseracing Commission's decision to approve a tobacco management plan for the facility as part of the OTB's gaming license and (2) that the exception was not motivated by the City's receipt of gaming revenues as had been true in the Evansville case. ${ }^{11}$

The trial court granted summary judgment for the City and the OTB. ${ }^{12}$ The Indiana Court of Appeals reversed, holding the City's proffered justification for treating the OTB and the plaintiff bar owners differently - the state regulation of the OTB - was too attenuated from the statutes at issue and from the stated purpose of the ordinance. ${ }^{13}$ It upheld all the other exceptions and severed the OTB exception so that the ordinance would remain otherwise intact. ${ }^{14}$

In Sasso v. State Farm Mutual Automobile Insurance Co. ${ }^{15}$ the Indiana Court of Appeals was confronted with claims that the Indiana Guest Statute-which prohibits negligence claims among family members and certain others arising from automobile accidents - violated article 1, sections 12 and article 1, section 23 of the Indiana Constitution. After finding the statute applied to foreclose a daughter's claim against the driver (her mother) notwithstanding the daughter's nominal payments for food and gas during the trip, the court held the statute violated neither constitutional provision. ${ }^{16}$ The court reaffirmed the Indiana Supreme Court's 1936 holding under the prior Guest Statute that the current law was a reasonable exercise of the legislature's power to address the general

7. 36 N.E.3d 1118 (Ind. Ct. App. 2015), aff'd in part, rev'd in part, 2016 WL 1425373 (Ind. April 11, 2016).

8. Id. at 1122 .

9. Id.

10. Paul Stieler Enters., Inc. v. City of Evansville, 2 N.E.3d 1269 (Ind. 2014).

11. Whistle Stop Inn, Inc., 36 N.E.3d at 1127.

12. Id. at 1123 .

13. Id. at 1128-29.

14. Id. at $1129-30$.

15. 43 N.E.3d 668, 669-70 (Ind. Ct. App. 2015), trans. denied, 48 N.E.3d 317 (Ind. 2016).

16. Id. at 676 . 
welfare and rejected the article 1 , section 12 claim. ${ }^{17}$

The court further upheld the statute as against the article 1 , section 23 challenge, finding the law's

disparate treatment ... for close family members of the motor vehicle operator is reasonably related to the inherent differences between the distinguished classes [because] it is reasonable for our legislature to suppose that close family members of a motor vehicle operator are more likely to engage in collusive lawsuits than persons more attenuated in their relationships to the motor vehicle operator. ${ }^{18}$

In Young v. Indiana Department of Correction, a pro se prisoner challenged a policy of the Indiana Department of Corrections ("DOC") that permits goodtime credit petitions only with respect to a sentence the prisoner is then serving, not with respect to sentences completed or discharged. ${ }^{19}$ The Indiana Court of Appeals held DOC's policy did not violate the Equal Privilege and Immunities Clause because there was no disparate treatment actually accorded by the policy. ${ }^{20}$ Therefore, the court rejected the plaintiff's premise that consecutive sentences for multiple convictions should be viewed as one sentence for purposes of good-time credit application. ${ }^{21}$

In Schaadt v. State ${ }^{22}$ and Whittaker v. State ${ }^{23}$ two panels of the Indiana Court of Appeals held the General Assembly's decision to not apply certain statutory sentencing reforms retroactively did not violate the Equal Privileges and Immunities Clause.

\section{Right to COMPENSATION}

In Snyder v. Town of Yorktown, a property owner brought an inverse condemnation claim against the town and local drainage board for failure to provide just compensation under the Indiana takings clause after she claimed those governmental entities had improperly entered her property and installed a drainage pipe. ${ }^{24}$ The trial court dismissed the claim under Trial Rule 12(B)(6) because the property owner had failed to name a lienholder, her mortgagee bank, in violation of the inverse condemnation statute. ${ }^{25}$ The court of appeals reversed, holding that although the statute did require naming all lienholders, such a failure

17. Gallegher v. Davis, 183 A. 620 (Del. 1936).

18. Sasso, 43 N.E.3d at 675.

19. Young v. Ind. Dep't of Corr., 22 N.E.3d 716 (Ind. Ct. App. 2014), trans. denied, 29 N.E.3d 124 (Ind. 2015).

20. Id. at 719 .

21. Id.

22. 30 N.E.3d 1 (Ind. Ct. App.), trans. denied, 32 N.E.3d 239 (Ind. 2015).

23. 33 N.E.3d 1063 (Ind. Ct. App. 2015).

24. Snyder v. Town of Yorktown, 20 N.E.3d 545 (Ind. Ct. App. 2014), trans. denied, 28 N.E.3d 246 (Ind. 2015).

25. Id. at 550 . 
was "not jurisdictional" and did not warrant dismissal of the property owner's claim. ${ }^{26}$ The court did not expressly state whether the property owner's assertion of a claim to vindicate a constitutional right played a role in excusing the property owner's pleading defect, but rather referred to the procedural mechanisms that were available to join the lienholder. ${ }^{27}$

Zoeller v. Sweeney involved a constitutional challenge to the Indiana "right to-work" law. ${ }^{28}$ A union and several of its members sued the Indiana Attorney General and the Commissioner of the Indiana Department of Labor, asserting the law-which prohibits employers from requiring union membership or the payment of monies as a condition of employment - violated article 1, section 21 of the Indiana Constitution by taking a person's "particular services" without compensation. ${ }^{29}$ The essence of the claim was that unions are required to provide certain services to bargaining unit employees regardless of whether they are union members, but the right-to-work law forbade unions from requiring compensation from those employees. ${ }^{30}$ The trial court agreed and held the statute unconstitutional. ${ }^{31}$ The Indiana Supreme Court disagreed and reversed the trial court's judgment. ${ }^{32}$

The supreme court's decision focused on two principle points. ${ }^{33}$ First, the court held the right-to-work law's enforcement mechanisms did not "demand" services from unions within the meaning of that test announced in Bayh $v$. Sonnenburg. ${ }^{34}$ Rather, on the face of the statute there was no state demand for services - the law merely prohibits employers from requiring union membership or the payment of monies as a condition of employment. ${ }^{35}$ Second, the court rejected the union's argument that unions effectively had an obligation under federal labor law to represent all bargaining unit employees. ${ }^{36}$ The court held a union's "federal obligation to represent all employees in a bargaining unit is optional; it occurs only when the union elects to be the exclusive bargaining agent, for which it is justly compensated by the right to bargain exclusively with the employer." ${ }^{37}$

\section{Separation of Powers}

In Indiana Department of Natural Resources v. Whitetail Bluff, LLC, the

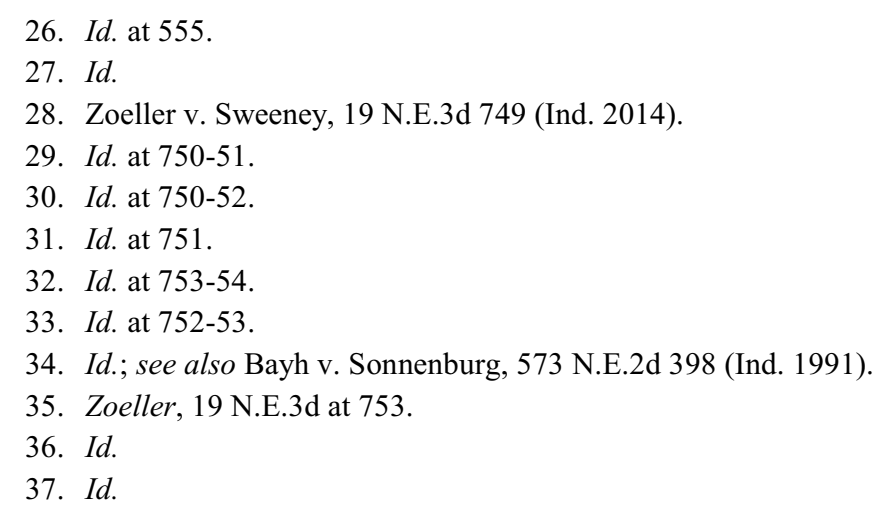


court of appeals sustained the practice of high-fence hunting of privately owned whitetail deer by finding that relevant statutes did not give the Department of Natural Resources ("DNR") authority to protect and manage wild animals legally owned or held in captivity under a license or permit. ${ }^{38}$ In construing the applicable statutes to find a lack of regulatory authority conferred upon the DNR, the court avoided substantial inquiry into a constitutional question raised by the plaintiff game farm that the DNR had violated separation of powers principles in promulgating rules forbidding high-fence hunting. ${ }^{39}$ Chief Judge Vaidik dissented and would have found the statutes in question permitted such regulation. ${ }^{40}$

Orange v. Morris concerned the procedures used to accomplish judicial mandates. ${ }^{41}$ The East Chicago City Court judge sued the East Chicago City Council alleging certain cuts to her budget would leave her without a way to meet all of the court's funding responsibilities. ${ }^{42}$ The judge styled her complaint as one for mandate. ${ }^{43}$ The trial was held in the Lake Circuit Court after which the court entered a mandate order effectively forbidding the Council's budget cuts. ${ }^{44}$ The Council appealed and sought immediate review from the Indiana Supreme Court in part on the basis that the Council was arguing the supreme court should have been involved in the case from the beginning under Trial Rule 60.5's procedures for judicial mandate. ${ }^{45}$

The supreme court denied immediate transfer and the court of appeals heard the case. ${ }^{46}$ The parties presented, in part, dueling arguments regarding separation of powers concerning (a) how much or how little a fiscal body should interact with a court before imposing budget cuts and (b) what deference the reviewing courts in judicial mandate cases owe fiscal bodies. ${ }^{47}$ The court of appeals held (1) the evidence was sufficient to support finding that funds requested by the city court judge were reasonably necessary for court operation and (2) a city court judge (as opposed to state superior courts and the Marion County Small Claims courts, which are all established solely by statute) was not required to adhere to procedural requirements of trial rules governing proceedings for mandate of funds. ${ }^{48}$

38. Ind. Dep't of Nat. Res. v. Whitetail Bluff, LLC, 25 N.E.3d 218 (Ind. Ct. App.), trans. denied, 31 N.E.3d 977 (Ind. 2015).

39. Id. at 226.

40. Id. at 230-31 (Vaidik, C.J., dissenting).

41. Orange v. Morris, 23 N.E.3d 787 (Ind. Ct. App. 2014).

42. Id. at 789-90.

43. Id. at 789 .

44. Id.

45. Id.

46. $I d$.

47. Id.

48. Id. at 797-98. 


\section{EDUCATION}

In Hoagland v. Franklin Township Community School Corp., parents brought a class action against Franklin Township Community School Corporation alleging its decision to discontinue transportation for a majority of students attending its public schools following a budget deficit was prohibited by the Education Clause of the Indiana Constitution. ${ }^{49}$ The trial court entered summary judgment for the school corporation and the court of appeals affirmed in part and reversed in part. ${ }^{50}$ The supreme court granted transfer and affirmed the judgment of the trial court. ${ }^{51}$ Justice David's opinion for the court traced the history of the Education Clause, article 8, section 1, and the supreme court's limited precedent interpreting it. ${ }^{52}$

Justice David acknowledged the purpose of the Education Clause is to foster and encourage education and the Indiana General Assembly is duty-bound to provide for a general and uniform system of common schools. ${ }^{53}$ Justice David also noted the Indiana General Assembly is afforded considerable discretion in determining the facets of a common school system. ${ }^{54}$ Reviewing the statutes that made school transportation voluntary, the court held the legislature's decision to permit, but not require, transportation did not violate the Education Clause. ${ }^{55} \mathrm{In}$ so doing, the court approved, for constitutional purposes, the rationale of its earlier decision in State ex. rel. Beard v. Jackson, ${ }^{56}$ which held the Indiana General Assembly had not required school transportation as a statutory matter. ${ }^{57}$

\section{SPEECH}

In Jordan v. State, ${ }^{58}$ the court of appeals reversed a conviction for misdemeanor disorderly conduct because it violated the free speech clause of the Indiana Constitution. ${ }^{59}$ Article 1, section 9 states: "No law shall be passed, restraining the free interchange of thought and opinion, or restricting the right to speak, write, or print, freely, on any subject whatever: but for the abuse of that right, every person shall be responsible." ${ }^{\prime 00}$ Jordan's conviction after a bench trial stemmed from a verbal altercation after police pulled her over and decided to tow the vehicle for registration issues. ${ }^{61}$ Using the two-step inquiry from Barnes $v$.

\footnotetext{
49. Hoagland v. Franklin Twp. Cmty. Sch. Corp., 27 N.E.3d 737 (Ind. 2015).

50. Id. at 740 .

51. Id. at 749 .

52. Id. at 746-47.

53. Id. at 738 .

54. Id. at 744 .

55. Id. at 749 .

56. 81 N.E. 62 (Ind. 1907).

57. $I d$. at 64 .

58. 37 N.E.3d 525 (Ind. Ct. App. 2015).

59. Id. at 553 .

60. IND. CONST. art. $1, \S 9$.

61. Jordan, 37 N.E.3d at 528-30.
} 
State,${ }^{62}$ the court found the officers restricted Jordan's expressive activity and her expressive activity did not amount to a public nuisance. ${ }^{63}$

The court rejected the State's argument that statements questioning why the officers asked Jordan whether she had a weapon, that the officers needed religion, and that they could not "'handle a Black woman"” were not political speech. ${ }^{64}$ Jordan's statement that she did not need to leave the scene, despite the officer's command for her to leave, focused criticism on police conduct. ${ }^{65}$ The court also found Jordan's statements did not cause anyone harm above the level of a "fleeting annoyance." ${ }^{66}$ Thus, the State could not punish Jordan for her speech. ${ }^{67}$

\section{SEARCh ANd Seizure}

In Carpenter v. State ${ }^{68}$ the Indiana Supreme Court held police officers' warrantless entry of a home, in response to a report of backyard dogfighting, violated the Indiana Constitution prohibition against unreasonable searches. ${ }^{69}$ Article 1, section 11 provides the "right of the people to be secure in their persons, houses, papers, and effects, against unreasonable search or seizure, shall not be violated." ${ }^{70}$ This language aligns with the Fourth Amendment to the U.S. Constitution. ${ }^{71}$ Yet Indiana courts have long separately analyzed searches based on whether the police conduct was reasonable under the totality of the circumstances. ${ }^{72}$ Fourth Amendment analysis turns on whether the search's subject has a "reasonable expectation of privacy." Constitution, bears the burden of showing the intrusion's reasonableness. ${ }^{74}$ The court looks at "1) the degree of concern, suspicion, or knowledge that a violation has occurred, 2) the degree of intrusion the method of the search and seizure imposes on the citizen's ordinary activities, and 3) the extent of law enforcement needs." 75

First, the State did not suggest entry was founded upon a "concern, suspicion, or knowledge that a violation [had] occurred." ${ }^{176}$ Instead, police entered the home

62. 946 N.E.2d 572 (Ind.), aff'd on reh'g, 953 N.E.2d 473 (Ind. 2011).

63. Jordan, 37 N.E.3d at 531-33.

64. Id. at 532 .

65. Id. at 532-33.

66. Id. at 533 .

67. Id.

68. 18 N.E.3d 998 (Ind. 2014).

69. Id. at 1000, 1003.

70. InD. Const. art 1, 11.

71. U.S. Const. amend. IV.

72. Carpenter, 18 N.E.3d at 1001-02.

73. $I d$.

74. Id. at 1002 (quoting Litchfield v. State, 824 N.E.2d 356, 361 (Ind. 2005)).

75. Id.

76. Id. 
to ensure the safety of anyone who may have been in need of help. ${ }^{77}$ This weighed against the search's legality ${ }^{78}$ Second, the intrusion was into the home, which receives the highest protection and is presumptively unreasonable absent a warrant.$^{79}$ Lastly, the officers did not need to enter the home.$^{80}$ Threats to the public were slim and the dog was confined behind a locked gate. ${ }^{81}$ The appearance of a dog acting aggressively and bloodied did not confer a reasonable belief that an individual was in danger. ${ }^{82}$ The court cautioned that an animal's condition or behavior could give rise to reasonable grounds to enter a residence under different circumstances. ${ }^{83}$

In C.P. v. State ${ }^{84}$ the court of appeals disagreed with an earlier decision of the same court and refused to apply the exclusionary rule where the defendant committed a new and distinct crime after an illegal seizure. ${ }^{85}$ The court readily determined the police officer violated the defendant's rights under article 1, section 11 and the Fourth Amendment. The officer lacked any suspicion or concern that a crime had been committed ${ }^{86}$ The defendant was merely wearing baggy pants and swearing, which violated the policy of the church that hired the officer for security-related purposes ${ }^{87}$ Despite the non-existent police needs, the officer placed his hand on the defendant's shoulder. ${ }^{88}$ This minimal restraint to guide the defendant off the church's property was an illegal seizure. ${ }^{89}$

Yet the defendant then committed a "new and distinct crime" when he battered the officer. ${ }^{90}$ Under the Fourth Amendment, excluding the evidence of this crime served no purposes - it would not deter future police misconduct. ${ }^{91}$ The court found the same applied under article 1, section 11-the defendant committed a "new crime" and thus the court properly admitted evidence of the battery even though police obtained the evidence after an illegal seizure. ${ }^{92}$ The court expressly disagreed with Trotter $v$. State, ${ }^{93}$ which rejected this "attenuation" doctrine as inapplicable under article 1 , section $11 .{ }^{94}$

77. Id.

78. Id.

79. Id.

80. Id. at 1003 .

81. Id.

82. Id.

83. $I d$.

84. 39 N.E.3d 1174 (Ind. Ct. App.), trans. denied, 39 N.E.3d 381 (Ind. 2015).

85. Id. at $1183-84$.

86. Id. at 1179 .

87. Id.

88. Id.

89. Id.

90. Id. at 1182 .

91. Id.

92. Id. at $1182-84$.

93. 933 N.E.2d 572 (Ind. Ct. App. 2010).

94. C.P., 39 N.E.3d at 1183. 
In a series of cases, the court of appeals found certain police conduct violated article 1 , section $11,{ }^{95}$ but reversed a trial court's order suppressing evidence in State $v$. Terrell, ${ }^{96}$ finding a search was "not unreasonable" when the defendant consented to the search, the police officer suspected the presence of a firearm, and the defendant was on probation. ${ }^{97}$ Similarly, in Bradley v. State,${ }^{98}$ the court of appeals found the police officers' belief that someone had apparent authority to consent to an entry of the home made an entry to the home reasonable under article 1, section $11 .{ }^{99}$ A subsequent protective sweep of the kitchen, given the officers' high safety concerns, was also deemed reasonable. ${ }^{100}$

\section{Rights of the Accused And Victims}

The court of appeals held in a 2-1 decision in Dunn $v$. State ${ }^{101}$ that the trial court was precluded from revoking a court-accepted plea agreement. ${ }^{102}$ The defendant had no right to the plea agreement, but once the trial court accepted the agreement, the court lacked power to revoke or withdraw it. ${ }^{103}$ The only exceptions, according to the majority, are when the defendant claims innocence before sentencing or when the defendant breaches the agreement. ${ }^{104}$

Judge Barnes dissented on the basis that article 1, section 13(b), a provision added in 1996, provides crime victims the constitutional right "to be informed of and present during public hearings and to confer with the prosecution, to the extent that exercising these rights does not infringe upon the constitutional rights of the accused." 105 The prosecutor's failure to consult with the victim before the plea agreement violated the victim's constitutional rights. ${ }^{106}$ Although the victim did not control the prosecution of the plea bargaining process, the prosecutor could resubmit the plea agreement after consulting with the victim and give the

95. See Garcia v. State, 25 N.E.3d 786 (Ind. Ct. App. 2015) (holding a search of a small metallic cylinder in the pants pocket of an individual arrested for misdemeanor driving without a license was illegal because the officer had no safety concerns to justify opening the container and no reasonable suspicion that the container held illegal substances), vacated, 47 N.E.3d 1196 (Ind. 2016); Mundy v. State, 21 N.E.3d 114 (Ind. Ct. App. 2014) (finding police entry past a driveway blocked by a padlocked cable, monitored by a security camera, and marked with a security sign and no trespassing sign was illegal); N.S. v. State, 25 N.E.3d 198 (Ind. Ct. App. 2015) (holding evidence discovered because of an illegal search was inadmissible as "fruit of the poisonous tree").

96. 40 N.E.3d 501 (Ind. Ct. App. 2015).

97. Id. at 506-07.

98. 44 N.E.3d 7 (Ind. Ct. App. 2015).

99. Id. at 20 .

100. Id. at 21 .

101. 33 N.E.3d 1074 (Ind. Ct. App. 2015).

102. Id. at 1076 .

103. Id.

104. Id.

105. Id. (Barnes, J., dissenting).

106. Id. at 1077. 
victim the chance to be present at the change of plea hearing. ${ }^{107}$

In Esmond v. State, ${ }^{108}$ the court held a defendant who raises the insanity defense does not have the right to counsel during examination by the State's expert provided the expert only testifies to the defendant's mental health and not guilt. ${ }^{109}$ Article 1, section 13(a), which affords Hoosiers greater protection than the federal Sixth Amendment counterpart, provides that the accused "shall have the right ... to be heard by himself and counsel." ${ }^{110}$ However, because Esmond did not develop an argument that the court's analysis should be different, the court applied the federal "critical stage" test which looks at whether a particular proceeding confronts the defendant with the "intricacies of the law" or the prosecutor's advocacy. ${ }^{111}$ Because the examination's scope and nature went only to mental capacity and not to guilt, and because Esmond's counsel was on notice, the examination did not violate the right to counsel. ${ }^{112}$

\section{Double JeOPARDY}

Indiana constitutional principles against double jeopardy were violated in Bookwalter v. State when the defendant was convicted for dealing in a narcotic drug and possession of a narcotic drug. ${ }^{113}$ Article 1 , section 14 provides that "[n]o person shall be put in jeopardy twice for the same offense."114 Two offenses constitute the "same offense" if, with respect to either the (A) statutory elements of the crimes or (B) "actual evidence" used to convict the offense's elements establish the other offense's elements. ${ }^{115}$

Based on Quick v. State, ${ }^{116}$ which held possession is an inherently included lesser offense of dealing, the court ordered the lesser included offense vacated. ${ }^{117}$ The charging information failed to distinguish different quantities of drugs to support the possession and the dealing offenses. ${ }^{118}$

The Indiana Supreme Court affirmed in Cleary v. State ${ }^{119}$ that a defendant is not subject to double jeopardy upon retrial after a hung jury. The defendant's

107. Id.

108. 20 N.E.3d 213 (Ind. Ct. App. 2014).

109. Id. at 218 .

110. Id. at 215 .

111. Id.

112. Id. at 218; see also Mathews v. State, 26 N.E.3d 130 (Ind. Ct. App. 2015) (finding waiver of the right to a face-to-face confrontation of a victim when the defendant failed to attend the victim's deposition).

113. Bookwalter v. State, 22 N.E.3d 735, 742 (Ind. Ct. App. 2014), trans. denied, 30 N.E.3d 1229 (Ind. 2015).

114. IND. CONST. art. $1, \S 14$.

115. Laramore \& Pulliam, supra note 1, at 1237.

116. 660 N.E.2d 598 (Ind. Ct. App. 1996).

117. $I d$. at 601 (citations omitted).

118. Id.

119. 23 N.E.3d 664 (Ind. 2015). 
retrial for causing death involved a single set of facts whereby the defendant, while drunk and during a sleet storm, crashed into a service vehicle and pinned the driver against a semi-truck. ${ }^{120}$ The second trial was simply a continuation of the jeopardy the defendant faced at the first trial. ${ }^{121}$ The court distinguished the case from Garrett v. State, ${ }^{122}$ where double jeopardy barred the State from retrying a defendant who received a hung jury on one charge of rape and was acquitted on the other on the basis the State failed to distinguish between the two incidents of rape.

In Hines v. State, ${ }^{123}$ the Indiana Supreme Court addressed whether there was a reasonable possibility the evidence used by the fact-finder to establish battery may have also been used to establish a confinement. Hines had lunged towards a correctional officer, striking her in the ribs and pinning her to the wall. ${ }^{124} \mathrm{He}$ then hit her head against a filing cabinet or the wall, held her in a headlock, and held his hand over her mouth and face. ${ }^{125}$

The court found this to be sufficient evidence to support both criminal confinement and battery; however, that did not end the case. ${ }^{126}$ The prohibition against double jeopardy in Indiana requires the State to prosecute the case in a manner that assures multiple guilty verdicts do not rest on the same evidence. ${ }^{127}$ Here, a reasonable possibility existed that the jury mixed the evidence because the State failed to allege and communicate specifically which different evidence supported each charge. ${ }^{128}$ Without a specific allegation regarding what different evidence supported what charge, and with evidence of two batteries related to the headlock, a reasonable possibility existed the jury based the battery and the criminal confinement conviction "on one continuous assault." 129

In three cases, the court of appeals reversed double jeopardy sua sponte as each case involvement the violation of a defendant's fundamental rights, ${ }^{130}$ but

120. Id. at 666 .

121. Id. at 674 (citation omitted).

122. 992 N.E.2d 710 (Ind. 2013).

123. 30 N.E.3d 1216 (Ind. 2015).

124. Id. at 1218 .

125. Id.

126. Id. at $1220-21$.

127. Id. at 1222 (citations omitted).

128. Id. at 1225 .

129. Id. at 1224 .

130. In White v. State, the court of appeals found two double jeopardy violations in the convictions of former Indiana Secretary of State Charles "Charlie" White. 25 N.E.3d 107, 130 (Ind. Ct. App. 2014), trans. denied, 34 N.E.3d 685 (Ind. 2015), cert. denied, 136 U.S. 595 (2015). First, the court found that White's conviction for class D felony submission of a fraudulent voter registration application and Class $\mathrm{D}$ felony perjury for making a false material statement under oath on his voter registration form rested on the same act. Id. at 130-31. The court also found that White's convictions for Class D felony voting and Class D felony casting a false ballot rested on the same act of voting outside the precinct in which he lived. Id. at 131.

In Hatchett v. State, the court held two convictions for invasion of privacy, based on the same 
rejected a claim in Singh v. State ${ }^{131}$ that convictions for attempted human trafficking and criminal confinement were barred by double jeopardy under the actual-evidence test. ${ }^{132}$

\section{Proportionality Clause}

Contrary to the Eighth Amendment, article 1, section 16 expressly provides all "penalties shall be proportioned to the nature of the offense." 133 Even though Indiana courts have said this provision sweeps "somewhat more broadly than the Eighth Amendment," courts have applied its protections narrowly. ${ }^{134}$

In Armstrong v. State, the court found a criminal gang enhancement statute did not violate the proportionality clause. ${ }^{135}$ The defendant, convicted of murder, attempted murder, and kidnapping, "basically tortured" the victims by tying zip ties around their necks and duct taping their heads. ${ }^{136}$ For habitual offender enhancements, courts look at the present crime's nature and gravity and the prior felonies' nature. ${ }^{137}$ Because the criminal gang enhancement did not rest on prior offenses, the court simply looked at whether the penalty was graduated and proportioned to the offense's nature. ${ }^{138}$ The criminal gang enhancement statute is graduated because the enhancement must equal the longest sentence imposed for an underlying felony. ${ }^{139}$ The enhancement was also proportioned to the offense's nature given the murder's circumstances. ${ }^{140}$

telephone call, violated double jeopardy. 33 N.E.3d 1125, 1130 (Ind. Ct. App. 2015). The State used the same telephone call to prove violation of a no-contact order and a protective order. Id.

The court of appeals also held in Phillips $v$. State that convictions for reckless homicide and involuntary manslaughter violated double jeopardy. 25 N.E.3d 1284, 1291-92 (Ind. Ct. App. 2015). Where the "gravamen of the offense is causing the death or injury of another person," such as murder, manslaughter, battery, and reckless homicide, the result is part of the crime's definition. Id. at 1291. The offenses' statutory elements aside, the State cannot convict someone of two separate homicides involving one death. Id.

131. 40 N.E.3d 981 (Ind. Ct. App. 2015), trans. denied, 43 N.E.3d 244 (Ind. 2016).

132. Id. at 987 . The court found the State's evidence in support of human trafficking included keeping the victim in his apartment and soliciting sexual contact from the victim for money, dragging the victim by the hair, and beating the victim. Id. The evidence in support of criminal confinement was limited to driving the victim in a semi-truck over the course of four days. $I d$.

133. IND. CONST. art. $1, \S 16$.

134. Armstrong v. State, 22 N.E.3d 629, 638 (Ind. Ct. App. 2014), trans. denied, 24 N.E.3d 967 (Ind. 2015).

135. Id. at 639 .

136. Id. at 635 (citation omitted).

137. Id. at 638 .

138. Id. at 638-39.

139. Id. at 639 .

140. Id. 


\section{BAIL}

In Satterfield v. State, ${ }^{141}$ the court of appeals reversed a trial court's denial of bail because it refused to weigh evidentiary facts suggesting self-defense to a murder charge. Notably, the court found a defendant's untimely notice of appeal did not forfeit his right to appeal because of the "extraordinarily compelling reasons" for restoring the right to appeal. ${ }^{142}$ Article 1 , section 17 provides that "[o]ffenses, other than murder or treason, shall be bailable." ${ }^{143}$ Yet, under Fry $v$. State, ${ }^{144}$ another murder case, the State had the burden of showing bail was inappropriate. The State was required to show the defendant more likely than not committed the crime of murder or treason. ${ }^{145}$

The court in Satterfield went a step further and found a defendant may also present evidence to rebut a State's presumption the defendant committed murder. ${ }^{146}$ The language of article 1 , section 17 did not limit the evidence admissible in such proceedings, and Indiana's Civil War-era precedents (the last time such showings were required before Fry) allowed defendants full constitutional due process rights in bail hearings. ${ }^{147}$ Thus, the trial court had to review Satterfield's evidence that the victim forcefully attempted to enter the car holding a shiny object before Satterfield fired a single shot at him with his gun. ${ }^{148}$

\section{Debts}

In a certified question from the U.S. Bankruptcy Court for the Northern District of Indiana, the court in In re Howell ${ }^{149}$ held article 1, section 22 did not override an Indiana law exempting life insurance policies from debtors' bankruptcy estate when the name beneficiary is a spouse, child, or other relative dependent on the debtor. Article 1, section 22 provides the

privilege of the debtor to enjoy the necessary comforts of life, shall be recognized by wholesome laws, exempting a reasonable amount of property from seizure or sale, for the payment of any debt or liability hereafter contracted: and there shall be no imprisonment for debt, except in case of fraud. ${ }^{150}$

Indiana courts find this language "commands the legislature to enact exemptions," but also define them in reasonable, tangible ways that balance

141. 30 N.E.3d 1271 (Ind. Ct. App. 2015).

142. Id. at 1275 .

143. InD. Const. art. $1, \S 17$.

144. 990 N.E.2d 429 (Ind. 2013).

145. Id. at 448 .

146. Satterfield, 30 N.E.3d at 1277.

147. Id.

148. Id.

149. 27 N.E.3d 723 (Ind. 2015).

150. IND. CONST. art. $1, \S 22$. 
lender and creditor interests. ${ }^{151}$

The court noted it had already deemed the life insurance policy exemption "constitutionally suspect," citing Citizens National Bank of Evansville v. Foster ${ }^{152}$ as it failed to contain an express upper limit. ${ }^{153}$ Yet the court found it could not address the statute's validity with a bright line rule. ${ }^{154}$ Instead, article 1 , section 22 violations must be determined on a case-by-case basis. ${ }^{155}$ Here, the cash value was significant but not inconsistent with the "necessary comforts of life." ${ }^{156}$ Furthermore, the Trustee had not claimed the cash value was "closeted in anticipation of bankruptcy." 157 The court, consistent with Foster, left it to the bankruptcy court to assess "reasonable necessity." 158

\section{Ex Post Facto}

Once again, Indiana courts applied the Ex Post Facto Clause to the laws governing convicted sex offenders. ${ }^{159}$ In Ammons v. State,${ }^{160}$ the court of appeals held retroactive application of the Indiana Sex Offender Registration Act was non-punitive as applied, and thus, did not violate constitutional prohibitions against ex post facto laws. Application of Indiana's constitutional provision requires use of the "intent-effects" test, which examines the scheme intended by the General Assembly. ${ }^{161}$ Because the Indiana Supreme Court held in State v. Pollard ${ }^{162}$ the law's intent was to create a civil, non-punitive regulatory scheme, the court had to consider whether the law's effects were so punitive as to an individual as to constitute a criminal penalty. ${ }^{163}$

The court of appeals applied the seven-factor test from Kennedy v. MendozaMartine $z^{164}$ to determine whether a law is an unconstitutional ex post facto law.

151. Howell, 27 N.E.3d at 728.

152. 668 N.E.2d 1236, 1242 (Ind. 1996).

153. Howell, 27 N.E.3d at 728.

154. Id.

155. Id. at 729 .

156. Id.

157. $I d$.

158. Id.

159. Ammons v. State, 36 N.E.3d 1079, 1082 (Ind. Ct. App. 2015), vacated, 2016 WL 1329583 (Ind. Apr. 5, 2016).

160. Id. at 1083 .

161. Id.

162. 908 N.E.2d 1145 (Ind. 2009).

163. Id. at 1149.

164. 372 U.S. 144 (1963); see Ammons, 36 N.E.3d at 1083 (quoting Wallace v. State, 905 N.E.2d 371, 379 (Ind. 2009)) (stating the seven factors to be "(1) whether the sanction involves an affirmative disability or restraint; (2) whether it has historically been regarded as punishment; (3) whether it comes into play only on a finding of scienter; (4) whether it promotes the traditional aims of punishment - retribution and deterrence; (5) whether the behavior to which it applies is already a crime; (6) whether it has a rational alternative purpose; and (7) whether it is excessive in relation 
First, the court of appeals recognized the law imposed substantial affirmative disabilities and restraints on Ammons as he had to give up an array of personal information to the public. ${ }^{165}$ The court noted the dissemination of that information resembled a "shaming" that could extend from ten years to life. ${ }^{166}$ Next, the court determined the law functioned punitively against Ammons because of registration's deterrent effect and the fact that when Ammons committed the offense, no registration requirements existed. ${ }^{167}$ The court recognized that although the sanction is often linked to crimes requiring mens rea, Ammons's offense (child molesting) did not require scienter. ${ }^{168}$ Yet the court determined registration advanced a non-punitive interest - protecting the public from repeat sexual crimes. ${ }^{169}$ Lastly, the court added the ability of an offender to obtain an individualized determination based on the likelihood to reoffend made the law less punitive. ${ }^{170}$

Although the court disclaimed relying on any particular factor as required by precedent, the court cited Ammons's ability to seek relief in concluding the law, as applied, did not violate the constitutional prohibition against ex post facto laws. ${ }^{171}$ Judge Barnes dissented on the basis that Wallace v. State ${ }^{172}$ required the trial court to grant Ammons's petition to be removed from the sex offender registry as Ammons had committed his crime before the registration requirement existed. ${ }^{173}$

In both State v. Zerbe ${ }^{174}$ and Tyson v. State ${ }^{175}$ the court of appeals held the sex offender law did not impose any additional punishment by requiring individuals to register when they move from a jurisdiction which already required that individual's registration. In both cases, the defendants moved from another state that imposed registration requirements for their prior convictions. ${ }^{176}$ The defendants argued, at the time of their offenses, Indiana did not require registration for their offenses or for individuals who move to Indiana from another state that requires registration. ${ }^{177}$ However, in both cases, the court found moving to Indiana did not trigger sex offender status - it simply maintained the

to the alternative purpose assigned.").

165. See Ammons, 36 N.E.3d at 1083.

166. Id. at 1084 .

167. Id. at $1084-85$.

168. Id. at 1084 .

169. Id. at 1085 .

170. Id. at 1086 .

171. Id. at 1087 .

172. 905 N.E.2d 371 (Ind. 2009).

173. Ammons, 36 N.E.3d at 1087-89 (Barnes, J., dissenting).

174. 32 N.E.3d 834, 838-39 (Ind. Ct. App. 2015), vacated, 2016 WL 756368 (Ind. Feb. 25, 2016).

175. 28 N.E.3d 1074, 1077 (Ind. Ct. App. 2015), vacated, 2016 WL 756366 (Ind. Feb. 25, 2016).

176. See id. at 1075; Zerbe, 32 N.E.3d at 835-36.

177. See Zerbe, 32 N.E.3d at 836; Tyson, 28 N.E.3d at 1075. 
status quo. ${ }^{178}$ Because the defendants had fair warning of Indiana's registration requirement, no Ex Post Facto Clause issues were triggered. ${ }^{179}$

Judge Baker dissented in Zerbe on the basis that Wallace v. State, ${ }^{180}$ finding that mandatory sex offender registration is punitive and that application of the requirement to offenders who committed their offenses before the law's enactment violated the Ex Post Facto Clause. ${ }^{181}$

\section{Unconstitutional Vagueness-Synthetic Drug Cases}

Two different decisions from the court of appeals came to different conclusions on whether the State's prohibition against synthetic drugs is unconstitutionally vague. ${ }^{182}$

In Elvers v. State, ${ }^{183}$ the court held the law satisfied article 4, section 20, which provides that "[e]very act and joint resolution shall be plainly worded, avoiding, as far as practicable, the use of technical terms." 184 The court recognized that in Kaur v. State, ${ }^{185}$ the court of appeals upheld the synthetic drug law against a vagueness challenge because the synthetic drug in question was specifically identified in the law. ${ }^{186}$ Yet Elvers argued the law was written "like a chemical engineer's dissertation, [such that] ordinary citizens, who are supposed to be at the top of the power-chain, will not know what is proscribed." 187

The court noted the law listed substances such as JWH-122 (1-pentyl-3-(4methyl-1-naphthoyl)indole) and JWH-250 (1-pentyl-3-)2methoxyphenylacetyl)indole), but disagreed that the list was too technical because the "novelty, complexity, and rapidly-evolving nature of synthetic drugs" required scientific terminology. ${ }^{188}$ The Indiana General Assembly only had to avoid technical terms to the extent practicable. ${ }^{189}$ A scientist from the Indiana State Police Laboratory Division had explained because "the chemical composition of synthetic drugs varies," chemical analyses are necessary to determine whether a product contains an illegal drug. ${ }^{190}$ Identification of both the banned substances' name and its' chemical structures ensured individuals are

178. See Zerbe, 32 N.E.3d at 837; Tyson, 28 N.E.3d at 1077.

179. See Zerbe, 32 N.E.3d at 839; Tyson, 28 N.E.3d at 1077.

180. 905 N.E.2d 371 (Ind. 2009).

181. Zerbe, 32 N.E.3d at 839 (Baker, J., dissenting).

182. See infra text accompanying notes 184-92 and 193-97.

183. 22 N.E.3d 824 (Ind. Ct. App. 2014).

184. Id. at 830 .

185. 987 N.E.2d 164 (Ind. Ct. App. 2013).

186. Elvers, 22 N.E.3d at 830.

187. Id.

188. Id.

189. Id.

190. Id. 
only charged if found with a specifically proscribed compound. ${ }^{191}$

But in Tiplick v. State, ${ }^{192}$ a decision issued only a month after Elvers, the court of appeals held the synthetic drug statute's reference to Pharmacy Board Regulations violated void-for-vagueness principles. ${ }^{193}$ Tiplick maintained a person of common intelligence could not be expected to understand the Pharmacy Board's drug promulgations and findings. ${ }^{194}$ The court of appeals agreed. ${ }^{195}$ The statutory scheme requiring a citizen of ordinary intelligence to search through the criminal code, the administrative code, and yet-to-be codified agency rules for information regarding a substance created a "Where's Waldo" expedition. ${ }^{196}$ The court distinguished Kaur and Elvers on the basis that a statute specifically listed the drugs at issue. ${ }^{197}$

Judge Bailey dissented. ${ }^{198} \mathrm{He}$ disagreed with the majority's "Where's Waldo" characterization of the statutory scheme and asserted the chemical substance for which Tiplick was charged was appropriately published in an emergency rule. ${ }^{199}$ Judge Bailey characterized the void-for-vagueness argument as an attempt to claim ignorance of the law as a defense to criminal liability. ${ }^{200}$

\section{XiV. Multiple Constitutional Arguments}

In City of Greenfield v. Indiana Department of Local Government Finance, ${ }^{201}$ a City and local fire protection territory alleged a statute adjusting the territory's tax levy that applied only to fire territories in Hancock County violated the Indiana Constitution's regulation of local and special laws under article 4, sections 22 and 23. ${ }^{202}$ The Indiana Tax Court found the law was a special law because it applied only to fire territories in Hancock County. ${ }^{203}$ The court then held that although the special statute was not properly construed as a law regarding the assessment or collection of taxes (which would have made the law per se unconstitutional under article 4, section 22), the law was unconstitutional under article 4 , section 23 because it reasonably could have been made general. ${ }^{204}$

191. Id.

192. 25 N.E.3d 190 (Ind. Ct. App.), vacated, 43 N.E.3d 1259 (Ind. 2015).

193. Id. at 196.

194. Id. at 192 .

195. Id. at 195 (stating that "[n]o person of ordinary intelligence could determine what behavior is prohibited by the term 'synthetic drug' in Ind. Code $\S \S 35-48-4-10$ (a) and 11, based on Ind. Code $\S \S 35-31.5-2-321(9)$ and 25-26-13-4.1”).

196. Id.

197. Id. at 195-96.

198. Id. at 196 (Bailey, J., dissenting).

199. Id. at 197.

200. Id.

201. 22 N.E.3d 887 (Ind. T.C. 2014).

202. Id. at 891 .

203. Id. at 893 .

204. Id. at 895 . 
City of Indianapolis v. $\operatorname{Cox}^{205}$ is a companion case to Armour v. City of Indianapolis, ${ }^{206}$ which held the City of Indianapolis's decision to transition from a Barrett Law (owner-funded) mechanism to a STEP program (City-funded) mechanism did not violate the Fourteenth Amendment's Equal Protection Clause by not retroactively relieving property owners of their Barrett Law assessments. ${ }^{207}$ In Cox, upon remand to state court from a federal district court after Armour, the trial court found the plaintiff homeowners had waived their constitutional arguments under the Uniform Assessment and Taxation Clause, article 10, section 1, and Equal Privileges and Immunities Clause, article 1, section 23, by not timely filing a notice under the Indiana Tort Claims Act. ${ }^{208}$ But Senior Judge Randall Shepard, sitting with the court of appeals, went on to address the constitutional issues in any event. ${ }^{209}$ The court held there was no violation of article 10 , section 1 , because the program was in the nature of debt forgiveness, not tax valuation. ${ }^{210}$ Additionally, the court held no Equal Privileges problem existed because "in drawing a classification between obligors who paid up front and those who financed, the City effected a 'reasonable relation of the disparate treatment to the inherent distinguishing characteristics of the two classifications." "'211

In Gul v. City of Bloomington, ${ }^{212}$ the Indiana Court of Appeals held a local ordinance restricting the height of grass on one's property did not violate the Freedom of Conscience Clause of article 1, section 3, or the Freedom of Speech Clause of article 1, section $9 .{ }^{213}$ The court found the freedom of conscience clause could only apply to religious matters of conscience, not "the right to act on one's own opinions in contravention of the law" such as one's sincerely held belief regarding the environmental harms of modern day lawn care. ${ }^{214}$ The court also found grass height restriction's limitation on the property owner's speech rational because of the harm non-maintained grass could have on neighborhood property values. ${ }^{215}$

In VanDam Estate v. Mid-America Sound, ${ }^{216}$ the Indiana Court of Appeals dealt with a claim arising from the Indiana State Fair stage collapse. ${ }^{217}$ One injured concert goer, who elected not to settle with the State when it offered the limits of the five million dollar aggregate liability cap of the Indiana Tort Claims

205. 20 N.E.3d 201 (Ind. Ct. App. 2014), trans. denied, 29 N.E.3d 124 (Ind. 2015).

206. 132 S. Ct. 2073 (2012).

207. Id. at $2078-84$.

208. Cox, 20 N.E.3d at 208.

209. See id. at 211-12.

210. See id. at 211.

211. Id. at 212 .

212. 22 N.E.3d 853 (Ind. Ct. App.), trans. denied, 33 N.E.3d 357 (Ind. 2014).

213. Id. at 863 .

214. $I d$. at 858 .

215. Id. at 860 .

216. 25 N.E.3d 165 (Ind. Ct. App.), trans. denied, 34 N.E.3d 250 (Ind. 2015).

217. See id. at 168 . 
Act, alleged the cap violated the Open Courts provision, article 1, section 12, and the Equal Privileges and Immunities Clause, article 1, section 23 of the Indiana Constitution. ${ }^{218}$ The court held (1) the aggregate liability cap is a rational means to achieve the legitimate legislative goal of protecting the public treasury and did not constitute a deprivation of a remedy for an established wrong and (2) that the cap's differentiation between individual and aggregate limits was rationally related to the State's interest in protecting the public. ${ }^{219}$

218. See id. at 167.

219. See id. at 170-72. 